\title{
Exogenous Application of Citric Acid Ameliorates the Adverse Effect of Heat Stress in Tall Fescue (Lolium arundinaceum)
}

\author{
Longxing Hu, Zhifei Zhang, Zuoxiang Xiang and Zhijian Yang* \\ Department of Turfgrass Sciences, College of Agronomy, Hunan Agricultural University, Changsha, China
}

\section{OPEN ACCESS}

Edited by:

Zhulong Chan,

Wuhan Botanical Garden, Chinese

Academy of Sciences, China

Reviewed by:

Glen Eris Aiken,

United States Department

of Agriculture - Agricultural Research

Service, USA

Zhaolong Wang,

Shanghai Jiao Tong University, China

*Correspondence:

Zhijian Yang

youtikenn@163.com

Specialty section: This article was submitted to Plant Physiology,

a section of the journal

Frontiers in Plant Science

Received: 12 November 2015

Accepted: 02 February 2016

Published: 18 February 2016

Citation:

Hu L, Zhang $Z$, Xiang $Z$ and Yang $Z$ (2016) Exogenous Application of Citric Acid Ameliorates the Adverse Effect of Heat Stress in Tall Fescue (Lolium arundinaceum).

Front. Plant Sci. 7:179 doi: 10.3389/fpls.2016.00179
Citric acid may be involved in plant response to high temperature. The objective of this study was to investigate whether exogenous citric acid could improve heat tolerance in a cool-season turfgrass species, tall fescue (Lolium arundinaceum), and to determine the physiological mechanisms of citric acid effects on heat stress tolerance. The grasses were subjected to four citric acid levels $(0,0.2,2$, and $20 \mathrm{mM})$ and two temperature levels (25/20 and $35 / 30 \pm 0.5^{\circ} \mathrm{C}$, day/night) treatments in growth chambers. Heat stress increased an electrolyte leakage (EL) and malonaldehyde (MDA) content, while reduced plant growth, chlorophyll (Chl) content, photochemical efficiency ( $F \vee / F m)$, root activity and antioxidant enzyme activities (superoxide dismutase, SOD; catalase, CAT; peroxidase, POD). External citric acid alleviated the detrimental effects of heat stress on tall fescue, which was evidenced by decreased EL and MDA content, and improved plant growth under stress conditions. Additionally, the reduction in Chl content, Fv/Fm, SOD, POD, CAT and root activity were ameliorated in citric acid treated plants under heat stressed conditions. High temperature induced the expression of heat shock protein (HSP) genes, which exhibited greater expression levels after citric acid treatment under heat stress. These results suggest that exogenous citric acid application may alleviate growth and physiological damage caused by high temperature. In addition, the exogenously applied citric acid might be responsible for maintaining membrane stability, root activity, and activation of antioxidant response and HSP genes which could contribute to the protective roles of citric acid in tall fescue responses to heat stress.

Keywords: heat stress, tall fescue, citric acid, antioxidant enzymes, heat shock proteins (HSP)

\section{INTRODUCTION}

High temperature is becoming one of the major factors limiting the growth and development of cool-season turfgrass (Larkindale and Huang, 2004). Generally the optimal temperatures for the growth and development of cool-season turfgrass species range from 15 to $24^{\circ} \mathrm{C}$ for shoots and 10 to $18^{\circ} \mathrm{C}$ for the roots (Paulsen, 1994); however, in transitional and warm climatic regions,

Abbreviations: CAT, catalase; Chl, chlorophyll; EDTA, ethylene diaminetetra acetic acid; EL, electrolyte leakage; $F \mathrm{v} / F \mathrm{~m}$, photochemical efficiency; HSP, heat shock protein; HMW-HSP, high molecular weight-HSP; HSP74.8, heat shock protein 74.8; HSC70, heat shock protein cognate 70; LMW-HSP, low molecular weight-HSP; MDA, malondialdehyde; NBT, nitro blue tetrazolium; PAR, photosynthetically active radiation; POD, peroxidase; ROS, reactive oxygen species; SOD, superoxide dismutase; TBA, thiobarbituric acid; TTC, triphenyl tetrazolium chloride. 
the temperature may peak to $38^{\circ} \mathrm{C}$ or higher during the summer. Therefore, the supraoptimal temperatures for prolonged periods often limit shoot and root growth, decline turf visual quality and root viability (Huang and Gao, 2000). In addition, high temperature would damage various physiological and metabolic processes that lead to premature leaf senescence (Liu and Huang, 2000; Huang et al., 2012). Heat stress induced senescence is associated with metabolic alterations as well as production of oxidative stress causing ROS in (Wahid et al., 2007). Oxidative stress can cause lipid peroxidation, membrane injury, protein degradation and enzyme inactivation in plants (Sairam et al., 2000; Meriga et al., 2004). However, plants have developed the enzymatic and non-enzymatic scavenging systems to scavenge the intra-cellar ROS (Liu and Huang, 2000). The enzymatic scavenging system includes SOD, which convert the superoxide radicals to hydrogen $\mathrm{POD}$, and the CAT and PODs (POD), which trigger the conversion of $\mathrm{H}_{2} \mathrm{O}_{2}$ to water and oxygen (Mittler, 2002).

Heat stress remarkably affects protein metabolism (Monjardino et al., 2005; He and Huang, 2007). Under high thermal conditions, normal proteins and mRNAs synthesis are inhibited. Conversely, transcription and translation of a HSPs may be triggered or enhanced when plants are subjected to elevated temperature (Vierling, 1991). The HSPs are molecular chaperones, which enhances plant tolerance to extreme heat shock conditions. The chaperons act by protecting the native proteins from denaturation, and thus improving protein stability under stresses (Schoffl et al., 1999). Based on their approximate molecular weight, the principal HSPs are grouped into three major families: LMW-HSP that range from 15 to $30 \mathrm{kDa}$, HSP70 ranging from 69 to $71 \mathrm{kDa}$ and HMW-HSP ranging from 80 to $114 \mathrm{kDa}$ (Mian et al., 2008). There is sufficient evidence that HSPs play crucial roles in thermotolerance, and that some specific HSPs causally participate in the acquisition of thermotolerance capacity (Wang et al., 2014). LMW-HSP genes such as ApHsp26.2 and ApHsp26.7a have been confirmed to accumulate highly in heat-tolerant creeping bentgrass (Wang and Luthe, 2003). In addition, the superior thermo-tolerance in higher plants was correlated with LMW-HSP (HSP18.1, HSP17.9) expression in wheat (Basha et al., 1999) and with $H M W-H S P$ (HSP101) expression in Arabidopsis (Queitsch et al., 2000).

Citric acid is one of the TCA intermediates, which serves as the source of carbon skeleton and cellular energy, which are utilized in the respiratory cycle and other biochemical pathways (da Silva, 2003). Citric acid as a vital organic acid, has been reported to be closely related with aluminum poisoning ( $\mathrm{Ma}$ and Furukawa, 2003), iron stress (Shlizerman et al., 2007), heavy metal stress tolerance (Gao et al., 2010) and salinity stress (Sun and Hong, 2011). In addition, citrate complex is one of the mobile forms of iron that participate in iron transportation inside plants (Hell and Stephan, 2003). Additionally, the complex has been confirmed to increase vase life and Chl content of tuberose and Lilium (Darandeh and Hadavi, 2011). Previously, we reported that heat stress altered the leaf metabolic profiles of a cool-season grass species, tall fescue (Festuca arundinacea), and demonstrated that the citric acid served majorly as an antioxidant respiratory metabolism intermediate involving the defense pathways in response to high temperature (Zhao et al., 2015).

Tall fescue ( $F$. arundinacea Schreb) is one of the widely used cool season forage and turfgrass species because of its adaptability, yield and persistence. Natural populations are scattered from Northern Europe including the Mediterranean region to North Africa, the Middle East, central Asia and Siberia. The optimum growth temperature of tall fescue ranges from 15 to $25^{\circ} \mathrm{C}$. High temperatures of over $35^{\circ} \mathrm{C}$ in warm climate regions during summer are usually detrimental to turf quality and growth. Many approaches have been applied to improve whole-plant stress tolerance in cool-season turfgrass species, including exogenous application of cytokinins and ascorbic acid (Xu and Huang, 2009; Kumar et al., 2011), $\mathrm{Ca}^{2+}$ (Jiang and Huang, 2001a) and salicylic acid (He et al., 2005). Previously, endogenous citric acid have been reported in response to heat stress, and mainly served as antioxidant and intermediate in respiration metabolisms involving the defense pathways in adaptation to high temperature (Zhao et al., 2015). However, there is unreliable evidence regarding the protective roles of exogenous citric acid on cool season turfgrass species under heat stress conditions.

The objective of this study was to investigate if the exogenously applied citric acid improve tolerance to heat stress by modulation of plant growth, leaf senescence, root activity, antioxidant capacity and HSP gene expressions in the cool-season grass tall fescue.

\section{MATERIALS AND METHODS}

\section{Plant Materials and Growth Conditions}

Twenty-five seeds of tall fescue 'Bar Lexus' were sowed in plastic pots (9-cm upper diameter, $7-\mathrm{cm}$ lower diameter, 12$\mathrm{cm}$ height) filled with peat soil and sand with the ratio of $1: 1$ $(\mathrm{v} / \mathrm{v})$. After germination, 15 uniform seedlings were allowed to grow and watered every other day with tap water. All plants were placed in a controlled walk-in growth room for 50 days with the temperature of $25 / 20 \pm 0.5^{\circ} \mathrm{C}$ (day/night), a $12-\mathrm{h}$ photoperiod, and a PAR of $240 \mu \mathrm{mol} \mathrm{m}^{-2} \mathrm{~s}^{-1}$ at the canopy level. Turf was hand-clipped at 6-cm canopy height three times per week. Plants were fertilized weekly with $300 \mathrm{ml}$ of halfstrength Hoagland nutrient solution per pot (Hoagland and Arnon, 1950). After 50 days of growth, plants were transferred to growth chambers (HP1500 GS-B; Wuhan Ruihua Instrument \& Equipment, Wuhan, China) for 5 days before treatments were imposed with the temperature of $25 / 20 \pm 0.5^{\circ} \mathrm{C}$ (day/night), a 12-h photoperiod, and a PAR of $400 \mu \mathrm{mol} \mathrm{m}^{-2} \mathrm{~s}^{-1}$ at the canopy level.

\section{Treatment and Experiment Design}

Plants were subjected to the following two temperature treatments for 15 days: control: plants were maintained at the optimal temperature $\left(25 / 20 \pm 0.5^{\circ} \mathrm{C}\right.$, day/night); heat stress: plants were exposed to supraoptimal temperatures of $10^{\circ} \mathrm{C}$ above the optimum range $\left(35 / 30 \pm 0.5^{\circ} \mathrm{C}\right.$, day/night). All plants were 
watered daily to maintain the soil water content at field capacity. The two temperature treatments were repeated three times on three different sets of plants. All growth chambers had a 12-h photoperiod, PAR of $400 \mu \mathrm{mol} \mathrm{m}^{-2} \mathrm{~s}^{-1}$, and 70 to $80 \%$ relative humidity.

Citric acid treatments were applied to the plants 3 days before the imposition of high temperature treatment, and then applied weekly during the period of temperature treatments. For citric acid treatment, plants in each plastic pot were foliar sprayed with $20 \mathrm{ml}$ of $0,0.2,2$, and $20 \mathrm{mM}$ sodium citrate solution (Sigma-Aldrich, St. Louis, MO, USA) until the turf grass canopy was saturated and some dripping occurred. Treatments were arranged as a split-plot design with temperature treatments as main plots and citric acid treatments as subplots. Each temperature and citric acid treatment had four replicates. All pots were randomized within the growth chamber.

After 15 days of heat stress, the shoots and roots were harvested for physiological analysis.

\section{Measurements}

Vertical shoot growth rate was estimated by measuring the difference in average turf canopy height before and after treatment using a ruler according to the method described by $\mathrm{Hu}$ et al. (2012). After 15 days of treatment, both shoots and roots were harvested separately and dry weights were recorded.

To determine EL, $0.1 \mathrm{~g}$ fully expanded leaves were washed three times with deionized water and placed in tubes filled with $15 \mathrm{ml}$ deionized water after cut to $0.5 \mathrm{~cm}$ long segments, and then shaken for $24 \mathrm{~h}$. The initial conductivity (Ci) was determined using a conductivity meter (JENCO-3173, Jenco Instruments, Inc., San Diego, CA, USA). The tubes were autoclaved at $121^{\circ} \mathrm{C}$ for $20 \mathrm{~min}$, and the conductivity of the incubation solution with killed tissues $\left(C_{\max }\right)$ was determined after the solution cooled to room temperature. Relative EL was calculated using the formula: $\mathrm{EL}(\%)=\left(C \mathrm{i} / C_{\max }\right) \times 100$.

Leaf Chl content was measured by using a hand-held Chl meter (SPAD-502 Plus, Minolta Corp., Spectrum Technologies, Inc.). The measurement points were randomly selected on the third fully developed leaves from top, and four points were selected on each leaf for all leaves in one pot (Richardson et al., 2002).

Leaf $F \mathrm{v} / \mathrm{Fm}$ (maximum quantum efficiency of PSII) was estimated by measuring the ratio of variable to maximum fluorescence of $\mathrm{Chl}(\mathrm{Fv} / F \mathrm{~m})$ with a Chl fluorometer (Walz, Effeltrich, Germany). Measurements were made on intact leaves with the fluorometer after plants were adapted in darkness for $30 \mathrm{~min}$.

Root activity was determined by the TTC method (Clemensson-Lindell, 1994). Briefly, $0.5 \mathrm{~g}$ fresh root was immersed in $10 \mathrm{ml}$ of equally mixed solution of $0.4 \%$ TTC and phosphate buffer, and kept in the dark at $37^{\circ} \mathrm{C}$ for $2 \mathrm{~h}$. Subsequently, $2 \mathrm{ml}$ of $1 \mathrm{M} \mathrm{H}_{2} \mathrm{SO}_{4}$ was added to stop the reaction with the root. The root was dried with filter paper and then extracted with ethyl acetate. The red extract was transferred into the volumetric flask to reach $10 \mathrm{ml}$ by adding ethyl acetate. The absorbance of the extract at $485 \mathrm{~nm}$ was recorded.
Root activity was expressed as TTC reduction intensity. Root activity $=$ amount of TTC reduction $(\mu \mathrm{g}) /$ fresh root weight (g) $\times$ time $(\mathrm{h})$.

For the determination of SOD, POD, CAT activity and MDA content, about $0.3 \mathrm{~g}$ of fully developed leaves was sampled at 15 days of treatment, frozen immediately with liquid nitrogen, and then stored at $-80^{\circ} \mathrm{C}$ for subsequent analysis. Frozen leaves were homogenized in $50 \mathrm{mM}$ ice-cold phosphate buffer $(\mathrm{pH}$ 7.0) with a pre-chilled mortar and pestle. The homogenate was centrifuged at $12,000 \times g$ for $15 \mathrm{~min}$ at $4^{\circ} \mathrm{C}$. The supernatants were collected to determine soluble protein, enzyme activities, and MDA content. Protein content was quantified using the method described by Bradford (1976).

The SOD activity was determined using the method described by $\mathrm{Hu}$ et al. (2012). Briefly, the color reaction contained $50 \mathrm{mM}$ of sodium phosphate buffer ( $\mathrm{pH} 7.0$ ), $1.125 \mathrm{mM}$ NBT, $1.3 \mathrm{mM}$ of riboflavin (7,8- dimethyl-10-ribitylisoalloxazine), $13 \mathrm{mM}$ of methionine, $75 \mathrm{nM}$ of EDTA and $100 \mathrm{ml}$ of enzyme extract with non-enzyme solution as control. The reaction mixtures were illuminated under a set of $40-\mathrm{W}$ fluorescent tubes (Philips, Amsterdam, Netherlands) for $20 \mathrm{~min}$. The changes of absorbance at $560 \mathrm{~nm}$ were determined with a spectrophotometer (UV-2600). One unit of enzyme activity was defined as the amount of enzyme required to inhibit the NBT reduction by $50 \%$.

The activities of CAT and POD were measured using the method of Chance and Maehly (1955). For CAT, the decomposition of $\mathrm{H}_{2} \mathrm{O}_{2}$ was measured by the decline in absorbance at $240 \mathrm{~nm}$ for $1 \mathrm{~min}$. The 3-ml reaction mixture contained $50 \mathrm{mM}$ phosphate buffer ( $\mathrm{pH} 7.0$ ), $15 \mathrm{mM} \mathrm{H}_{2} \mathrm{O}_{2}$, and $0.1 \mathrm{ml}$ enzyme extract, which initiated the reaction. For POD, the oxidation of guaiacol was measured by the increase in absorbance at $470 \mathrm{~nm}$ for $1 \mathrm{~min}$. The reaction mixture contained $50 \mu \mathrm{l}$ of $20 \mathrm{mM}$ guaiacol, $2.8 \mathrm{ml}$ of $10 \mathrm{mM}$ phosphate buffer $(\mathrm{pH} 7.0)$, and $0.1 \mathrm{ml}$ enzyme extract. The reaction was started with $20 \mu \mathrm{l}$ of $40 \mathrm{mM} \mathrm{H}_{2} \mathrm{O}_{2}$.

The MDA content was determined by the TBA reaction using the method described by Heath and Packer (1968). One milliliter of extract was mixed with $1 \mathrm{ml}$ of reaction solution containing 20\% (v/v) trichloroacetic acid and 0.5\% (v/v) TBA. The mixture was heated in a $95^{\circ} \mathrm{C}$ water bath for $30 \mathrm{~min}$, then cooled to room temperature, and centrifuged at $10,000 \mathrm{~g}$ for $10 \mathrm{~min}$. The supernatant was read for absorbance at 532 and $600 \mathrm{~nm}$. The absorbance for non-specific absorption at $600 \mathrm{~nm}$ was subtracted from the value at $532 \mathrm{~nm}$. The content of MDA was calculated using the adjusted absorbance and the extinction coefficient of $155 \mathrm{mM}^{-1} \mathrm{~cm}^{-1}$ (Heath and Packer, 1968).

Leaf citric acid content was determined according to the highperformance liquid chromatography (HPLC) method described by Shui and Leong (2002) with slight modifications. Briefly, $0.5 \mathrm{~g}$ of fresh samples was ground into fine powder in liquid nitrogen, and then homogenized in $5 \mathrm{ml}$ ultra-pure water. The homogenate was centrifuged at $5000 \mathrm{rpm}$ for $5 \mathrm{~min}$ at room temperature. The supernatants were filtered through a $0.22 \mu \mathrm{m}$ membrane filter and inject $10 \mu \mathrm{l}$ of volume to the reversed-phase HPLC (RP-HPLC) with an Agilent 1100 Series 
(Agilent Technologies, Atlanta, GA, USA) according to the $\mathrm{Hu}$ et al. (2015a). The citric acid was identified based on retention time and quantified based on the UV spectra relative to the standards.

Total RNA was extracted from fresh tissues by using Trizol reagent (Invitrogen, Carlsbad, CA, USA) according to the user manuals. After extraction, the RNA pellet was dissolved in $100 \mu \mathrm{l}$ of RNase-free water. RNase-free DNase I was added to the total RNA to remove DNA contamination. The total RNA concentration was then determined by absorbance at $260 \mathrm{~nm}$ and RNA quality was evaluated on a $0.8 \%$ agarose gel. The first strand cDNA fragments were synthesized from $2 \mu \mathrm{g}$ of total RNA using oligo(dT)12-18 primer using cDNA synthesis kit (Fermentas, Burlington, Ontario, Canada) according to the user manual. Gene-specific primers (Table 1) were designed based on the target gene sequences using Primer 5 software (Hu et al., 2015b). YT521-B gene was used as internal standard. The qRT-PCRs were performed with ABI7500 in a final volume of $20 \mu$, with each containing $2 \mu l$ of cDNA, $10 \mu \mathrm{l}$ of $2 \mathrm{x}$ SYBR Green qPCR Mix (Takara, Otsu, Shiga, Japan) and $2 \mu \mathrm{M}$ of the forward and reverse primers. Three independent biological replicates of each sample and two technical replicates of each biological replicate were used for real-time PCR analysis. The thermal cycling conditions were as follows: 40 cycles of $95^{\circ} \mathrm{C}$ denaturation for $5 \mathrm{~s}$, and $52-55^{\circ} \mathrm{C}$ annealing and extension for $20 \mathrm{~s}$. After the PCR, a melting curve was generated by gradually increasing the temperature to $95^{\circ} \mathrm{C}$ to test the amplicon specificity. To determine relative fold differences for each sample, the CT value for each gene was normalized to the CT value for the reference gene and was calculated relative to a calibrator using the DDCT method as described by Livak and Schmittgen (2001).

\section{Statistical Analysis}

All data were subjected to two-way ANOVA (analysis of variance) according to the general linear model procedure of SAS (SAS Institute, Cary, NC, USA) to determine the effects of temperature, citric acid and their interactions. Treatment means were separated using the Duncan's multiple range test at the $P=0.05$ level of probability.

TABLE 1 | Primer sequence used for real-time quantitative PCR.

\begin{tabular}{|c|c|c|c|c|}
\hline Gene name & Accession & Primers sequences $\left(5^{\prime}-3^{\prime}\right)$ & $\begin{array}{l}\text { Size } \\
\text { (bp) }\end{array}$ & $\begin{array}{l}\mathrm{Tm} \\
\left({ }^{\circ} \mathrm{C}\right)\end{array}$ \\
\hline HMW-HSP & DT697638 & $\begin{array}{l}\text { F TTGCAATAGATCGCAGTCAGGAG } \\
\text { R CACGAGGTGAGAGTTCGCATAAT }\end{array}$ & 113 & 55 \\
\hline HSC70 & CK800824 & $\begin{array}{l}\text { F CATCATCGGTITCGACAACATCC } \\
\text { R CCACGTCCAACATAAGCACAAGA }\end{array}$ & 187 & 55 \\
\hline OsHSP74.8 & AK073817 & $\begin{array}{l}\text { F CGAGCAGTTCGAGTACCAGG } \\
\text { R TCAGCCATAGCTTCCCATAC }\end{array}$ & 465 & 58 \\
\hline LMW-HSP & DT696482 & $\begin{array}{l}\text { F TCTGATCGTCTGCCATITCCTA } \\
\text { R GCCCGTGGTCAATCTCCTC }\end{array}$ & 109 & 55 \\
\hline YT521-B & & $\begin{array}{l}\text { F TGTAGCTTGATCGCATACCC } \\
\text { R ACTCCCTGGTAG CCACCTT }\end{array}$ & 122 & 55 \\
\hline
\end{tabular}

\section{RESULTS}

\section{High Temperature and Exogenous Citric Acid Induced Accumulation of Endogenous Citric Acid in Leaves of Tall Fescue}

In this study, to investigate the relationship between heat stress and citric acid content, the endogenous citric acid levels in leaves of tall fescue were quantified after treatments with high temperature $\left(35 / 30 \pm 0.5^{\circ} \mathrm{C}\right.$, day/night) for 15 days. In tall fescue leaves, heat stress significantly increased endogenous citric acid content when compared to the control plants (Figure 1). This result indicated that citric acid might be involved in heat stress response. Additionally, treatments with higher concentrations of citric acid resulted in higher accumulation of endogenous citric acid in both control and heat stressed plants, and the accumulation of citric acid content by exogenous application of citric acid was in a concentration-dependent manner (Figure 1).

\section{Exogenous Citric Acid Improved Heat Stress Tolerance in Tall Fescue}

Under optimum growth conditions, tall fescue growth was generally equivalent to the non-citric acid treated plants irrespective of foliar concentration of citric acids, as showed by the canopy height and plant dry weight (Figure 2). High temperature remarkably reduced plant growth in tall fescue as indicated by the lower canopy height and plant dry weight (Figure 2). However, the citric acid treatment alleviated the decline in canopy height and plant dry weight under heat stress as compared to the non-treated plants, particularly at $2 \mathrm{mM}$ concentration.

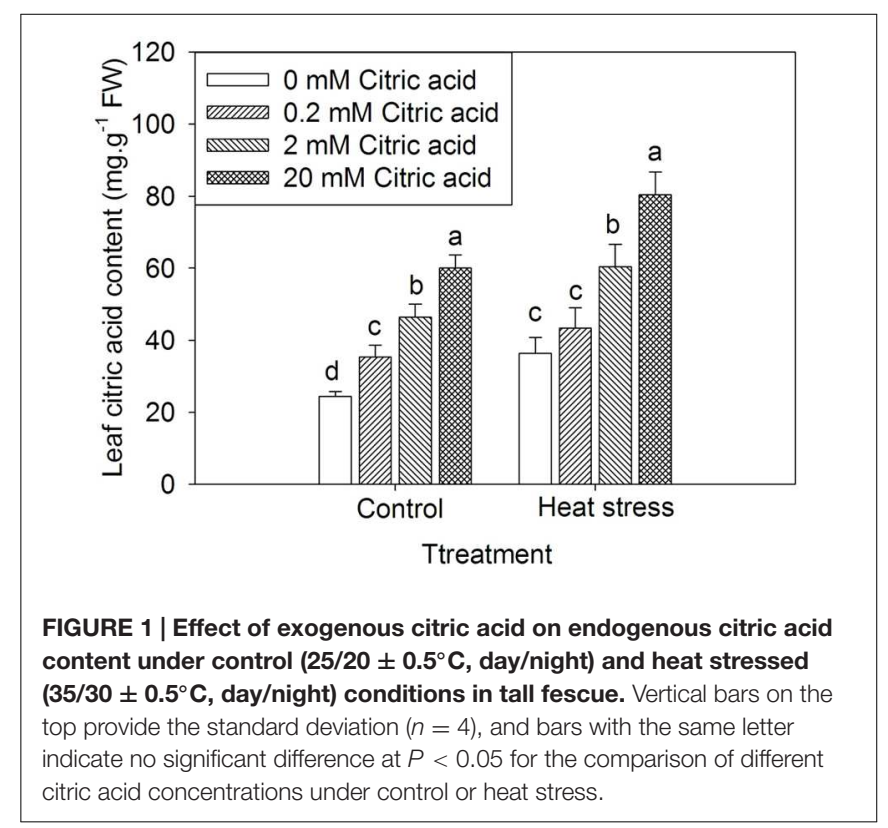



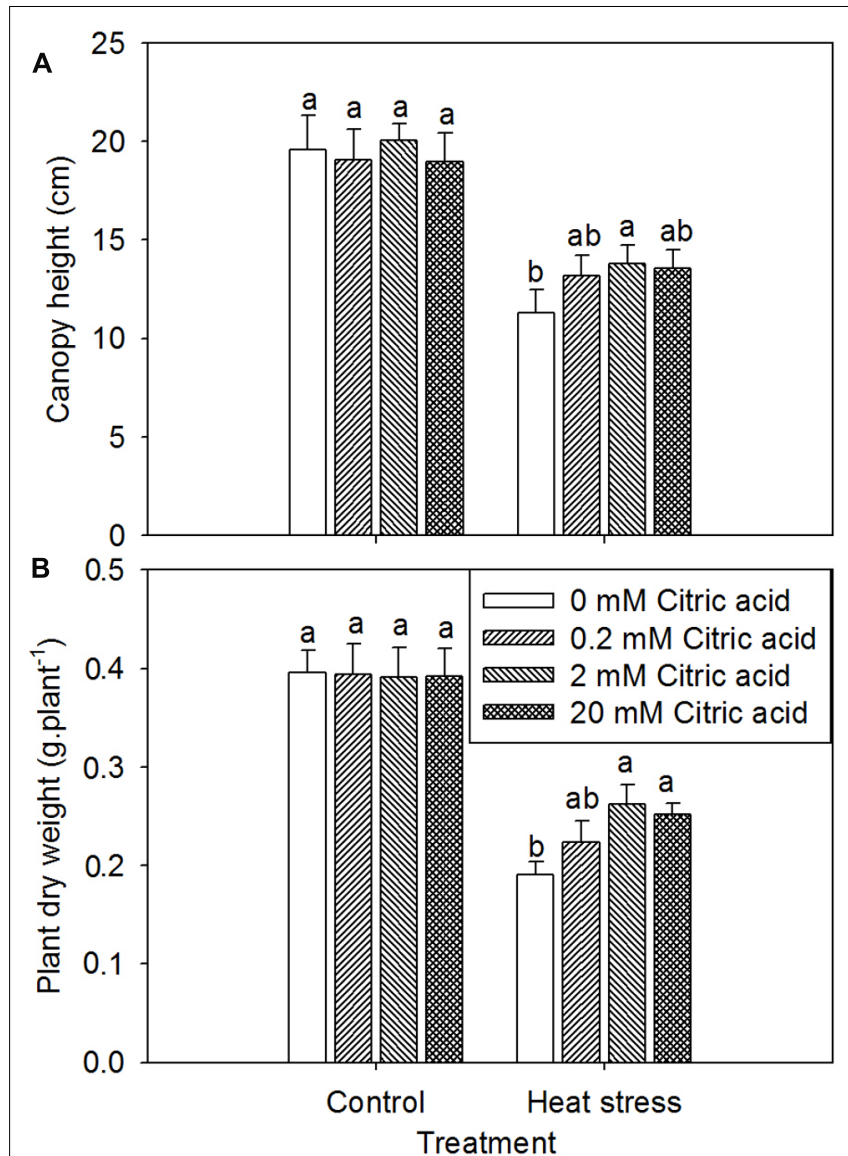

FIGURE 2 | Effect of exogenous citric acid on canopy height (A) and plant dry weight $(B)$ under control $\left(25 / 20 \pm 0.5^{\circ} \mathrm{C}\right.$, day/night) and heat stressed $\left(35 / 30 \pm 0.5^{\circ} \mathrm{C}\right.$, day/night) conditions in tall fescue. Vertical bars on the top provide the standard deviation $(n=4)$, and bars with the same letter indicate no significant difference at $P<0.05$ for the comparison of different citric acid concentrations under control or heat stress.

\section{Exogenous Citric Acid Alleviated the Damage Effect of Heat stress on Tall Fescue}

Leaf EL and MDA levels were generally employed to assess the extent of membrane damage caused by environmental stress. Treatment with citric acid alone had no effect on the leaf EL and MDA content under control growth conditions (Figure 3). Heat stress treatment significantly increased EL and induced the accumulation of MDA in leaves of tall fescue (Figure 3), while citric acid treated plants displayed significantly lower EL and MDA content in comparison with non-treated plants (Figure 3).

\section{Effect of Exogenous Citric Acid on Leaf Senescence and Photochemical Efficiency in Tall Fescue Under Heat Stress}

Leaf senescence was assessed from a decline in the Chl content based on a SPAD values. The $F \mathrm{v} / F \mathrm{~m}$ of photosynthesis II
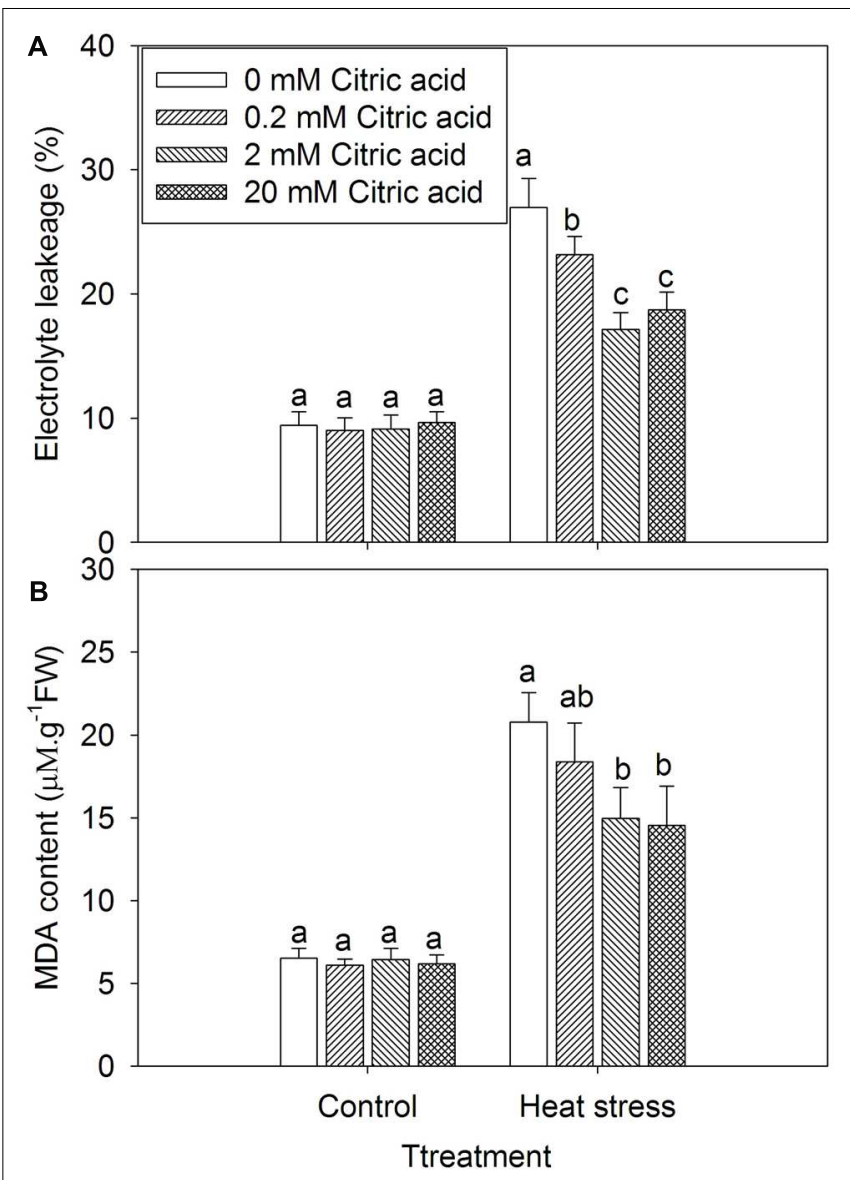

FIGURE 3 | Effect of exogenous citric acid on EL (A) and MDA content (B) under control $\left(25 / 20 \pm 0.5^{\circ} \mathrm{C}\right.$, day/night) and heat stressed (35/30 $\pm \mathbf{0 . 5} 5^{\circ} \mathbf{C}$, day/night) conditions in tall fescue. Vertical bars on the top provide the standard deviation $(n=4)$, and bars with the same letter indicate no significant difference at $P<0.05$ for the comparison of different citric acid concentrations under control or heat stress.

(PSII, Fv/Fm) was measured by analysis of Chl fluorescence. A significant decline in $\mathrm{Chl}$ content and $\mathrm{Fv} / \mathrm{Fm}$ in leaves of tall fescue was observed under heat stress, while treatment with different concentration of citric acid alone had no effect under control condition (Figures 4A,B). Under stress condition, however, citric acid treated plants displayed an increased Chl content and $F \mathrm{v} / F \mathrm{~m}$, particularly for the concentration of 2 and $20 \mathrm{mM}$, when compared to the $0 \mathrm{mM}$ citric acid in tall fescue (Figures 4A,B).

\section{Effect of Exogenous Citric Acid on Root Activity in Tall Fescue Under Heat Stress}

Reduction of TTC has been used frequently employed to assess the root metabolic activities in under various growth conditions. Heat treatment with or without citric acid addition resulted in a decreased root activity when compared to the control plants, irrespective of citric acid concentrations (Figure 5). Heat treatment plus citric acid at 2 and $20 \mathrm{mM}$ increased root activity by 32 and $25 \%$, respectively, when compared with heat treat 


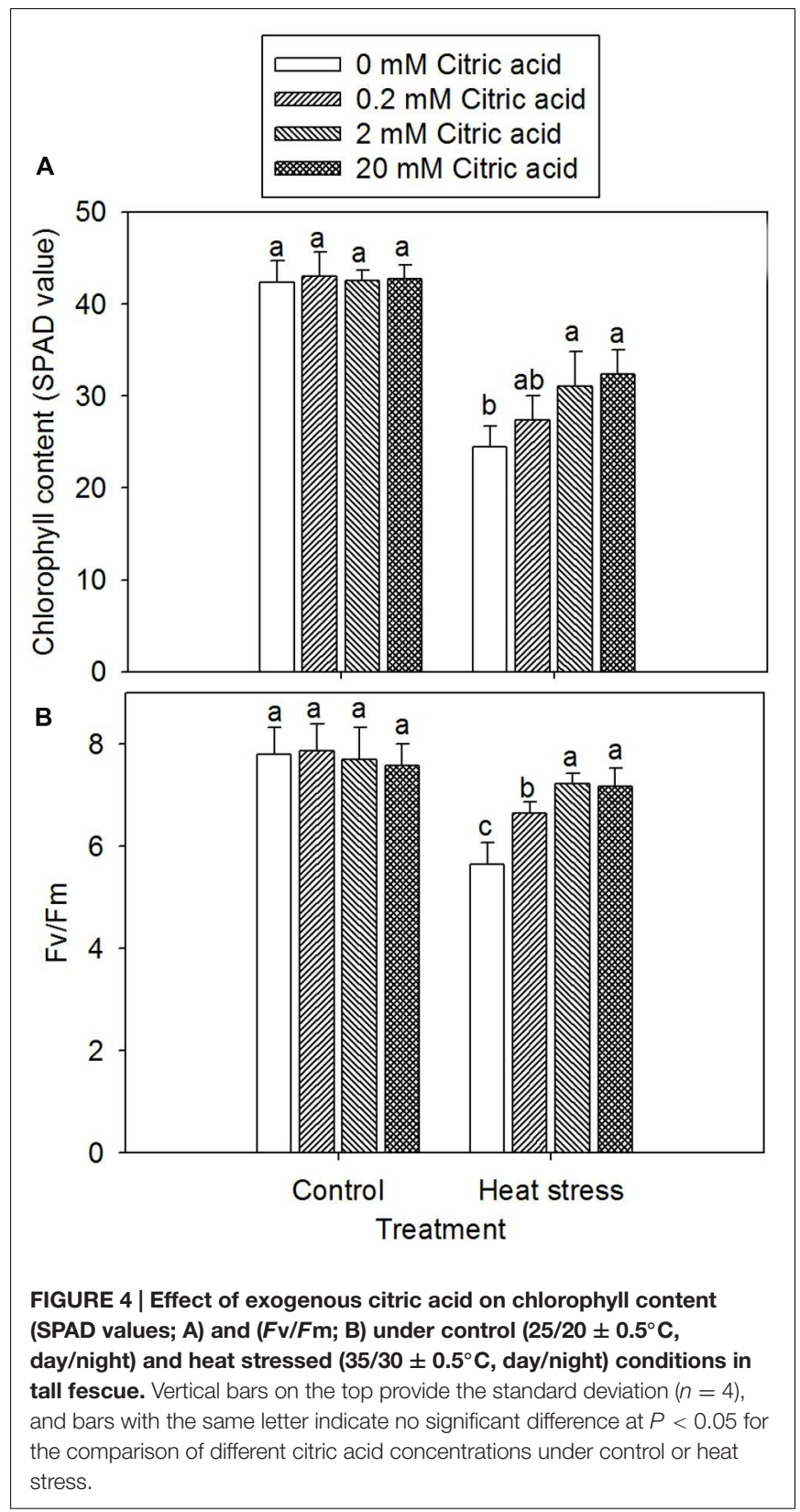

treatment alone. No significant difference among the four citric acid application levels was observed under control conditions (Figure 5).

\section{Effect of Exogenous Citric Acid on Antioxidant Activities in Tall Fescue Under Heat Stress}

On one hand, foliar application of exogenous citric acid alone had no effect on SOD, POD, and CAT activity under control condition (Figures 6A-C). Heat treatment led to the deactivation of these antioxidant enzymes irrespective of citric acid concentration, when compared to the control plants (Figures 6A-C). On the other hand, foliar application of exogenous citric acid improved

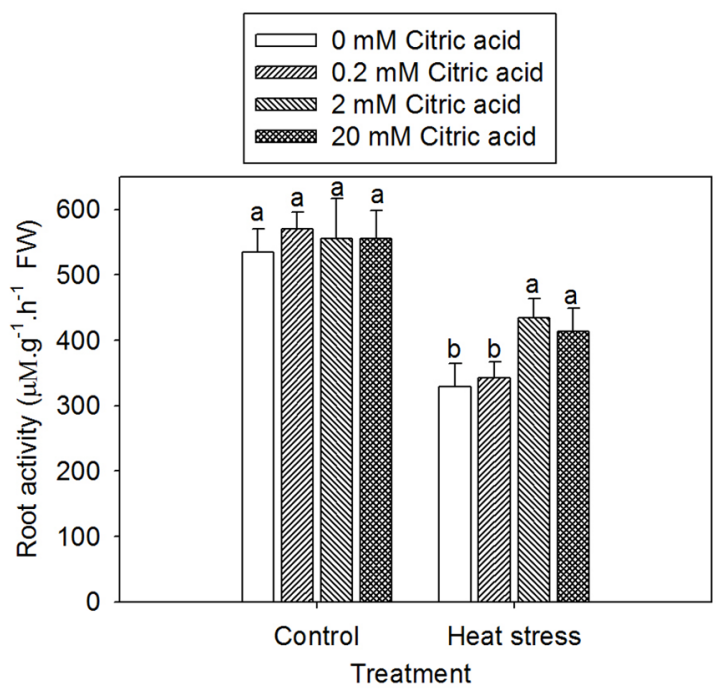

FIGURE 5 | Effect of exogenous citric acid on root activity under control $\left(25 / 20 \pm 0.5^{\circ} \mathrm{C}\right.$, day/night) and heat stressed $\left(35 / 30 \pm 0.5^{\circ} \mathrm{C}\right.$, day/night) conditions in tall fescue. Vertical bars on the top provide the standard deviation $(n=4)$, and bars with the same letter indicate no significant difference at $P<0.05$ for the comparison of different citric acid concentrations under control or heat stress.

the activities of SOD, POD, and CAT under heat stress, when compared to the non-citric acid treated plants, particularly with the concentration of 2 and $20 \mathrm{mM}$ (Figures 6A-C).

\section{Effect of Exogenous Citric Acid on the Expression of Heat Shock Proteins in Tall Fescue Under Heat Stress}

Exogenously applied citric acid alone had no significant effect on the expression levels of HSP gene families, including HMWHSP, LMW-HSP, HSP74.8, and HSC70 under control condition (Figures 7A-D). Heat stress induced higher expression levels of HSP HMW-HSP, LMW-HSP, HSP74.8, and HSC70 genes when compared to the control plants. Evidently, foliar application of 2 and $20 \mathrm{mM}$ concentration of exogenous citric acid significantly induced HSP gene expressions, when compared to the 0 and $0.2 \mathrm{mM}$ concentration of citric acid under heat stress condition (Figures 7A-D).

\section{DISCUSSION}

Our previous study demonstrated that heat stress substantially increased endogenous citric acid levels in tall fescue, and may be involved in high temperature adaptation (Zhao et al., 2015). Concurrently, other studies suggested that exogenous citric acid could promote growth and improve $\mathrm{Cd}$ and salinity stress tolerance in plants (Gao et al., 2010; Sun and Hong, 2011). In this study, the positive role of citric acid on tall fescue response to heat stress was assigned via exogenously applied citric acid. The results of this study indicated that exogenous application of citric acid alleviated detrimental effects of heat stress on tall fescue; this 

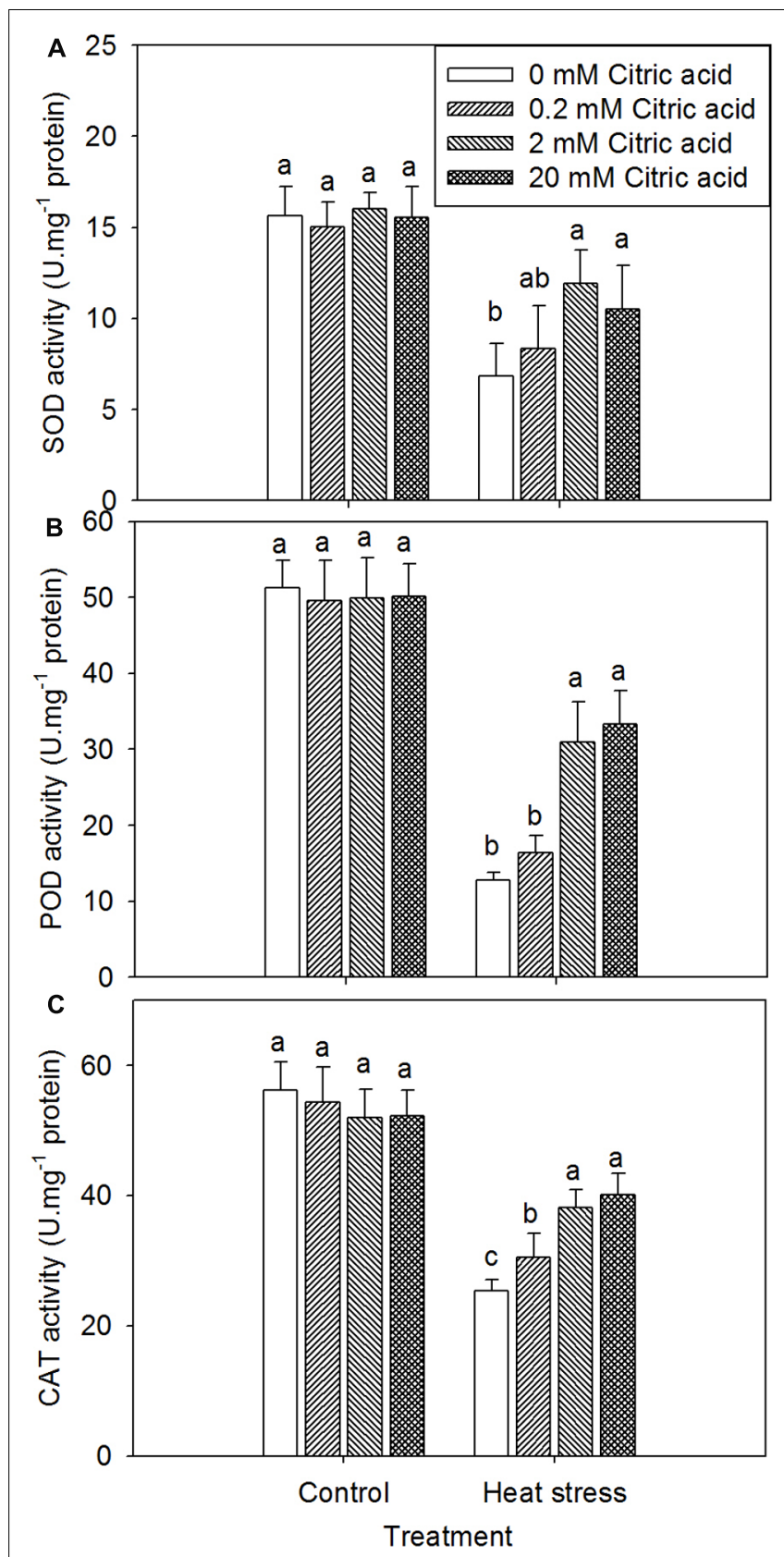

FIGURE 6 | Effect of exogenous citric acid on SOD (A), POD (B) and CAT (C) under control $\left(25 / 20 \pm 0.5^{\circ} \mathrm{C}\right.$, day/night) and heat stressed $\left(35 / 30 \pm 0.5^{\circ} \mathrm{C}\right.$, day/night) conditions in tall fescue. Vertical bars on the top provide the standard deviation $(n=4)$, and bars with the same letter indicate no significant difference at $P<0.05$ for the comparison of different citric acid concentrations under control or heat stress.

may be a practical approach to improve heat stress tolerance in cool-season turfgrass species during summer seasons.

Heat stress often triggers drastic changes in the cell membrane stability, and ultimately influences the sensors present in the membrane (Kumar et al., 2013). It is generally accepted that the maintenance of cell membrane integrity and stability under stress conditions is critical for plant survival (Blum and Ebercon,
1981). Marcum (1998) has shown that cell membrane stability was positively correlated to turf quality and can be used to predict the whole-plant heat tolerance in Kentucky bluegrass cultivars. The level of lipid peroxidation, expressed as MDA content, has been used as an indicator of free radical damage to cell membranes (Smirnoff, 1995). No significant changes in EL and MDA content were observed after citric acid treatment for tall fescue under control conditions (Figure 3). However, leaf EL and MDA in tall fescue increased under heat stress, but exogenous application of citric acid reduced lipid peroxidation, as indicated by the less accumulation of MDA and lower EL when compared to the untreated plants (Figure 3). These results suggested that application of citric acid would reduce loss of grasses under high temperature environments by mitigating oxidative stress.

In many plant species heat stress induces oxidative stress and alters the antioxidant activities of SOD, POD, and CAT enzymes (Jagtap and Bhargava, 1995; Gong et al., 1997), including turfgrass (Liu and Huang, 2000; Jiang and Huang, 2001a,b). SOD is responsible for catalyzing $\mathrm{O}_{2}{ }^{-}$into $\mathrm{H}_{2} \mathrm{O}_{2}$ in plants (Miller et al., 2010; Sharma et al., 2013). The increased SOD activity was considered a protective mechanism against the formation of superoxide under stress conditions (Ostrovskaya et al., 2009). In this study, the SOD activity decreased under high temperature stress in tall fescue, this observation was consistent with the previous studies that revealed a decrease in SOD activities in cool-season turfgrass (Du et al., 2009; He and Huang, 2010). The alleviation of the SOD activity reduction by exogenously applied citric acid in tall fescue under heat stress may have resulted in less production of $\mathrm{O}_{2}{ }^{-}$and thus lower heat induced oxidative damages in leaves.

Peroxidase and CAT are the major enzymes that convert $\mathrm{H}_{2} \mathrm{O}_{2}$ into $\mathrm{H}_{2} \mathrm{O}$, which are produced through the dismutation of $\mathrm{O}_{2}{ }^{-}$catalyzed by SOD (Miller et al., 2010; Sharma et al., 2013). The maintenance of higher POD and CAT activity may provide further oxidative protection by detoxifying $\mathrm{H}_{2} \mathrm{O}_{2}$ induced by heat stress through weakening the SOD enzyme system. In the present study, a decrease in POD and CAT activity were observed under heat stress conditions. These result suggested that high temperature triggered oxidative damage in leaves of tall fescue. The result further indicated that POD and CAT could be sensitive to high temperatures (Jiang and Huang, 2001a; He and Huang, 2010). Decrease in POD activity during heat stress have also been observed in other species, such as wheat (Almeselmani et al., 2006), rice (Shi et al., 2006), and mustard (Dat et al., 1998). In current study, external citric acid treatment helped to maintain higher POD and CAT activities when compared to the untreated plants under heat stress. These results indicated that the enhanced POD and CAT activities by exogenously applied citric acid might contribute to the reduced accumulation of $\mathrm{MDA}, \mathrm{H}_{2} \mathrm{O}_{2}$, and $\mathrm{O}_{2}{ }^{-}$ contents, and alleviate the damage to cell membranes.

Roots play a critical role in plant tolerance to elevated temperatures. It has been reported that the significance of these vital organs in plant adaptation to heat stress is associated with their participation in water and nutrient uptake, as well hormone synthesis affecting shoot growth and development (Jiang and Huang, 2001a). The detrimental effects of heat stress on the plant roots are typically characterized by a changes in root morphology 


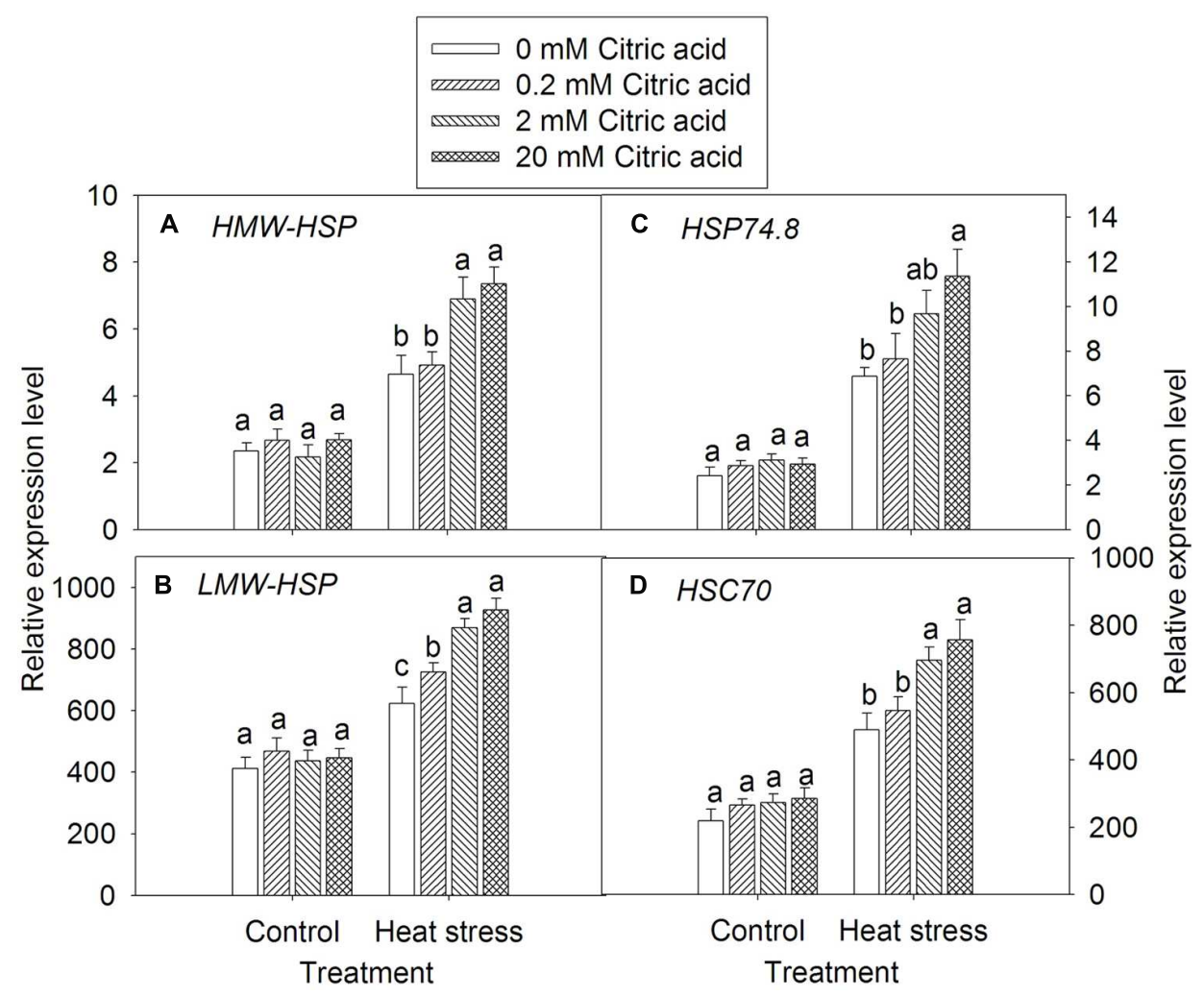

FIGURE 7 | Effect of exogenous citric acid on the expression of heat shock protein (HSP) gene family under control $\left(25 / 20 \pm 0.5^{\circ} \mathrm{C}\right.$, day/night) and

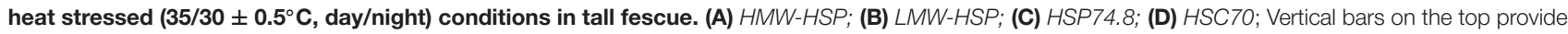
the standard deviation $(n=4)$, and bars with the same letter indicate no significant difference at $P<0.05$ for the comparison of different citric acid concentrations under control or heat stress.

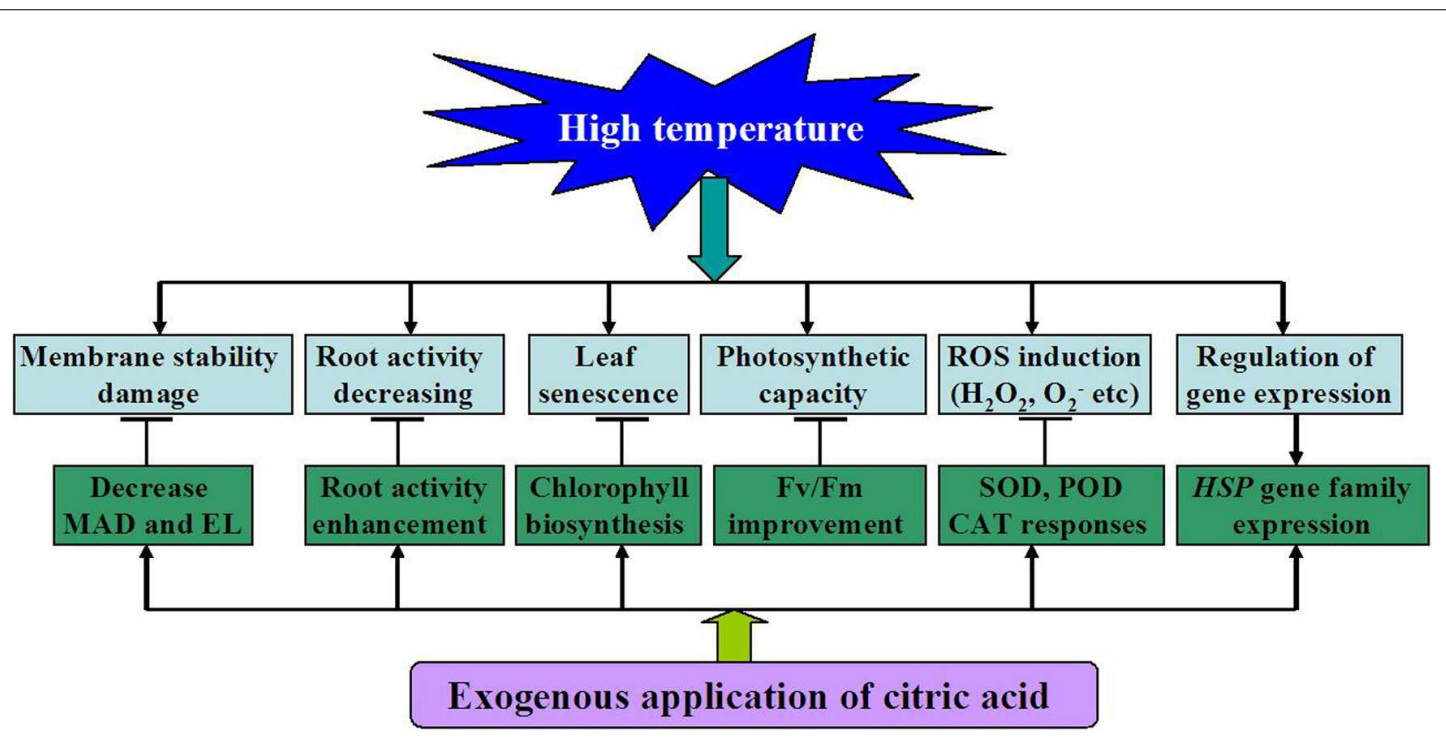

FIGURE 8 | A proposed model for citric acid-mediated high temperature stress responses in tall fescue.

as well as root metabolic activities ( $\mathrm{Xu}$ and Huang, 2000; Huang and Liu, 2003). In the present study, high temperatures significantly declined root activity along with a great reduction in shoot growth, suggesting that heat stress caused injurious effect on root growth and eventually preceded shoot growth inhibition in tall fescue, as indicated in previous studies 
(Du et al., 2009; Zhao et al., 2015). We also observed that exogenous application of citric acid alleviated the decrease in root activity and shoot growth (Figures 2 and 5). These results suggested that the exogenous citric acid ameliorated the heatinduced injury to plants. This could be possibly attributed to the improvement of root viability and functions, which were associated with water and nutrient uptake and transport to shoots (Huang and $\mathrm{Xu}, 2000$ ) as well as the synthesis of phytohormones in roots (Liu et al., 2002).

High temperatures during summer often cause leaf senescence and eventually decline in turf quality in cool-season turfgrass (Jiang and Huang, 2001b). Leaf Chl content is a good indicator of leaf senescence and an important factor determining photosynthetic capacity. Many have demonstrated that high temperatures result in declines in Chl content in cool-season turfgrasses, contributing to leaf senescence and photosynthesis inhibition under heat stress (Liu and Huang, 2000; Jiang and Huang, 2001b; Zhang et al., 2010). In this study, heat stress caused a decrease in $\mathrm{Chl}$ content and the maximum quantum yield of photosynthesis system II $(F \mathrm{v} / F \mathrm{~m})$. However, exogenous application of citric acid resulted in the alleviation of $\mathrm{Chl}$ and $F_{\mathrm{V}} / F_{\mathrm{m}}$ reduction in leaves of tall fescue under heat stress. These results suggested that external citric acid treatment might have been related to the inhibition and loss of Chl under heat stress, which damaged the reaction centers (Kyle, 1987). These changes improved the photosynthetic capacity by reducing photo-oxidation (Wise and Naylor, 1987) or maintaining photosynthetic membrane integrity (Coria et al., 1998).

The HSPs are molecular chaperones which played an important role in the heat shock tolerance under high temperatures conditions (Schoffl et al., 1999). The presence and role of HSPs in heat tolerance has been examined in various crops, such as rice (Oryza sp.), wheat (Triticum sp.), barley (Hordeum sp.) and oat (Avena sp.) (Xu et al., 2011). Some studies have reported that changes in specific HSP expressions are related to heat stress tolerance in cool-season turfgrass species, such as creeping bentgrass (Agrostis stolonifera) and fescues (Festuca sp.) (Xu et al., 2011). In this study, high temperature induced HSP family genes expressions in tall fescue, suggesting that up-regulation of HSPs, primarily LMW-HSP, HMW-HSP, HSC70, or HSP74.8 based on their molecular weights, is a typical response of tall fescue to heat stress. However, exogenous application of citric acid induced a higher expression of these HSP genes under high temperatures in tall fescue, especially

\section{REFERENCES}

Almeselmani, M., Deshmukh, P. S., Sairam, R. K., Kushwaha, S. R., and Singh, T. P. (2006). Protective role of antioxidant enzymes under high temperature stress. Plant Sci. 171, 382-388. doi: 10.1016/j.plantsci.2006.04.009

Basha, E. M., Waters, E. R., and Vierling, E. (1999). Triticum aestivum cDNAs homologous to nuclear-encoded mitochondrion-localized small heat shock proteins. Plant Sci. 141, 93-103. doi: 10.1016/S0168-9452(98) 00219-2

Blum, A., and Ebercon, A. (1981). Cell membrane stability as a measure of drought and heat tolerance in wheat. Crop Sci. 21, 43-47. doi: 10.2135/cropsci1981.0011183X002100010013x under high citric acid concentrations. These results suggested that the enhanced expression of this chaperone gene under heat stress as a result of exogenous application of citric acid is vital for heat tolerance in cool-season tall fescue (Tian et al., 2009; Xu et al., 2011).

Based on the above observations, a model for citric acidmediated heat stress response in tall fescue was proposed in this study (Figure 8). On one hand, heat stress had detrimental effects on the cell membrane, root activity, induced leaf senescence and ROS production. On the other hand, exogenous application of citric acid could promote antioxidant enzyme activities (SOD, POD, and CAT) and HSP family gene expressions, improve Chl biosynthesis and photosynthetic capacity. All these changes in turn alleviated cell membrane damages, ROS accumulation, leaf senescence and increased root activity all induced by high temperature.

\section{CONCLUSION}

Heat stress and external application of citric acid induced the accumulation of endogenous citric acid levels in tall fescue leaf tissues. Heat stress was detrimental to plant growth, cell membranes, root activity, and antioxidant enzyme activities in tall fescue. However, external application of citric acid alleviated the detrimental effects of heat stress on tall fescue. The beneficial effect of external application of citric acid in tall fescue in response to heat stress may attribute to its protective effects on peroxidation-linked membrane deterioration, free radicals scavenging, maintenance of membrane stability, increase in root activity and activation of antioxidant response and HSP genes.

\section{AUTHOR CONTRIBUTIONS}

$\mathrm{LH}$ and $\mathrm{ZY}$ conceived and designed the experiment. $\mathrm{LH}$ and $\mathrm{ZZ}$ conducted the experiment. ZX and LH analyzed data, LH and ZY wrote the manuscript. The authors read and approved the paper.

\section{ACKNOWLEDGMENTS}

This work was financial supported by the Scientific Research Fund of Hunan Provincial Education Department (Grant No. 14B083).

Bradford, M. M. (1976). A rapid and sensitive method for quantitation of microgram quantities of protein utilizing the principle of protein dye-binding. Anal. Biochem. 72, 248-254. doi: 10.1016/0003-2697(76) 90527-3

Chance, B., and Maehly, A. C. (1955). "Assay of catalases and peroxidases," in Methods in Enzymology, Vol. II, eds S. P. Colowick and N. O. Kaplan (New York, NY: Academic Press), 764-775.

Clemensson-Lindell, A. (1994). Triphenyltetrazolium chloride as an indicator of fine-root vitality and environmental stress in coniferous forest stands: applications and limitations. Plant Soil 159, 297-300. doi: 10.1007/BF00009293

Coria, N. A., Sarquis, J. I., Penalosa, I., and Urzua, M. (1998). Heat-induced damage in potato (Solanum tuberosum) tubes: membrane stability, tissue viability, 
and accumulation of glycoalkaloids. J. Agric. Food Chem. 46, 4524-4528. doi: $10.1021 /$ jf 980151

Darandeh, N., and Hadavi, E. (2011). Effect of pre-harvest foliar application of citric acid and malic acid on chlorophyll content and post-harvest vase life of Lilium cv. Brunello. Front. Plant Sci. 2:106. doi: 10.3389/fpls.2011.00106

da Silva, J. A. T. (2003). The cut flower: postharvest considerations. J. Biol. Sci. 3, 406-442. doi: 10.3923/jbs.2003.406.442

Dat, J. F., Lopez-Delgado, H., Foyer, C. H., and Scott, I. M. (1998). Parallel changes in $\mathrm{H}_{2} \mathrm{O}_{2}$ and catalase during thermotolerance induced by salicylic acid or heat acclimation in mustard seedlings. Plant Physiol. 116: 1351-1357. doi: 10.1104/pp.116.4.1351

Du, H. M., Wang, Z. L., and Huang, B. R. (2009). Differential responses of warm-season and cool-season turfgrass species to heat stress associated with antioxidant enzyme activity. J. Am. Soc. Hortic. Sci. 134, 417-422.

Gao, Y., Miao, C. Y., Mao, L., Zhou, P., Jin, Z. G., and Shi, W. J. (2010). Improvement of phytoextraction and antioxidative defense in Solanum nigrum L. under cadmium stress by application of cadmium-resistant strain and citric acid. J. Hazard. Mater. 181, 771-777. doi: 10.1016/j.jhazmat.2010. 05.080

Gong, M., Chen, S. N., Song, Y. Q., and Li, Z. G. (1997). Effect of calcium and calmodulin on intrinsic heat tolerance in relation to antioxidant systems in maize seedlings. Aust. J. Plant Physiol. 24, 371-379. doi: 10.1071/PP96118

He, Y. L., and Huang, B. R. (2007). Protein changes during heat stress in three Kentucky bluegrass cultivars differing in heat tolerance. Crop Sci. 47, 25132520. doi: $10.2135 /$ cropsci2006.12.0821

He, Y. L., and Huang, B. R. (2010). Differential responses to heat stress in activities and isozymes of four antioxidant enzymes for two cultivars of kentucky bluegrass contrasting in heat tolerance. J. Am. Soc. Hortic. Sci. 135, 116-124.

He, Y. L., Liu, Y., Cao, W., Huai, M., Xu, B., and Huang, B. R. (2005). Effects of salicylic acid on heat tolerance associated with antioxidant metabolism in Kentucky bluegrass. Crop Sci. 45, 988-995. doi: 10.2135/cropsci2003.0678

Heath, R. L., and Packer, L. (1968). Photoperoxidation in isolated chloroplasts. I. Kinetics and stoichiometry of fatty acid peroxidation. Arch. Biochem. Biophys. 125, 189-198. doi: 10.1016/0003-9861(68)90654-1

Hell, R., and Stephan, U. W. (2003). Iron uptake, trafficking and homeostasis in plants. Planta 216, 541-551. doi: 10.1007/s00425-002-0920-4

Hoagland, D. R., and Arnon, D. I. (1950). The Water-Culture Method for Growing Plants Without Soil, Circular 347. Berkeley, CA: University of California, Agricultural Experiment Station.

Hu, L. X., Hu, T., Zhang, X., Pang, H., and Fu, J. M. (2012). Exogenous glycine betaine ameliorates the adverse effect of salt stress on perennial ryegrass. J. Am. Soc. Hortic. Sci. 137, 38-46.

Hu, L. X., Zhang, P. P., Jiang, Y., and Fu, J. M. (2015a). Metabolomic analysis revealed differential adaptation to salinity and alkalinity stress in Kentucky bluegrass (Poa pratensis). Plant Mol. Biol. Rep. 33, 56-68. doi: 10.1007/s11105014-0722-4

Hu, T., Liu, S. Q., Amombo, E., and Fu, J. M. (2015b). Stress memory induced rearrangements of HSP transcription, photosystem II photochemistry and metabolism of tall fescue (Festuca arundinacea Schreb.) in response to hightemperature stress. Front. Plant Sci. 6:403. doi: 10.3389/fpls.2015.00403

Huang, B. R., and Gao, H. W. (2000). Root physiological characteristics associated with drought resistance in tall fescue cultivars. Crop Sci. 40, 196-203. doi: $10.2135 /$ cropsci2000.401196x

Huang, B. R., and Liu, X. Z. (2003). Summer root decline: production and mortality for four cultivars of creeping bentgrass. Crop Sci. 43, 258-265. doi: 10.2135/cropsci2003.2580

Huang, B. R., Rachmilevitch, S., and Xu, J. C. (2012). Root carbon and protein metabolism associated with heat tolerance. J. Exp. Bot. 63, 3455-3465. doi: $10.1093 /$ jxb/ers003

Huang, B. R., and $\mathrm{Xu}, \mathrm{Q}$. Z. (2000). Root growth and nutrient status of creeping bentgrass cultivars differing in heat tolerance as influenced by supraoptimal shoot and root temperatures. J. Plant Nutr. 23, 979-990. doi: $10.1080 / 01904160009382075$

Jagtap, V., and Bhargava, S. (1995). Variation in antioxidant metabolism of drought-tolerant and drought-susceptible varieties of Sorghum bicolor (L.) Moench. exposed to high light, low water and high temperature stress. J. Plant Physiol. 145, 195-197. doi: 10.1016/S0176-1617(11)81872-9
Jiang, Y. W., and Huang, B. R. (2001a). Effects of calcium on antioxidant activities and water relations associated with heat tolerance in two cool-season grasses. J. Exp. Bot. 52, 341-349. doi: 10.1093/jexbot/52.355.341

Jiang, Y. W., and Huang, B. R. (2001b). Drought and heat stress injury to two coolseason turfgrasses in relation to antioxidant metabolism and lipid peroxidation. Crop Sci. 41, 436-442. doi: 10.2135/cropsci2001.412436x

Kumar, R. R., Goswami, S., Sharma, S. K., Singh, K., Gadpayle, K. A., Singh, S. D., et al. (2013). Differential expression of heat shock protein and alteration in osmolyte accumulation under heat stress in wheat. J. Plant Biochem. Biotechnol. 22, 16-26. doi: 10.1007/s13562-012-0106-5

Kumar, S., Kaur, R., Kaur, N., Bhandhari, K., Kaushal, N., Gupta, K., et al. (2011). Heat-stress induced inhibition in growth and chlorosis in mungbean (Phaseolus aureus Roxb.) is partly mitigated by ascorbic acid application and is related to reduction in oxidative stress. Acta Physiol. Plant. 33, 2091-2101. doi: 10.1007/s11738-011-0748-2

Kyle, D. J. (1987). “The biochemical basis for photoinhibition of photosystem II," in Photoinhibition, eds D. J. Kyle, C. B. Osmond, and C. J. Arntzen (Amsterdam: Elsevier), 197-226.

Larkindale, J., and Huang, B. R. (2004). Changes of lipid composition and saturation level in leaves and roots for heat-stressed and heat-acclimated creeping bentgrass (Agrostis stolonifera). Environ. Exp. Bot. 51, 57-67. doi: 10.1016/S0098-8472(03)00060-1

Liu, X. Z., and Huang, B. R. (2000). Carbohydrate accumulation in relation to heat stress tolerance in two creeping bentgrass cultivars. J. Am. Soc. Hortic. Sci. 125, $442-447$.

Liu, X. Z., Huang, B. R., and Banowetz, G. (2002). Cytokinin effects on creeping bentgrass responses to heat stress I. Shoot and root growth. Crop Sci. 42, 457-465. doi: 10.2135/cropsci2002.4570

Livak, K. J., and Schmittgen, T. D. (2001). Analysis of relative gene expression data using real-time quantitative PCR and the 2- $\Delta \Delta \mathrm{CT}$ method. Methods 25, 402-408. doi: 10.1006/meth.2001.1262

Ma, J. F., and Furukawa, J. (2003). Recent progress in the research of external Al detoxification in higher plants: a minireview. J. Inorg. Biochem. 97, 46-51. doi: 10.1016/S0162-0134(03)00245-9

Marcum, K. B. (1998). Cell membrane thermostability and whole-plant heat tolerance of Kentucky bluegrass. Crop Sci. 38, 1214-1218. doi: 10.2135/cropsci1998.0011183X003800050017x

Meriga, B., Reddy, B. K., Rao, K. R., Reddy, L. A., and Kishor, P. B. (2004). Aluminium-induced production of oxygen radicals, lipid peroxidation and DNA damage in seedlings of rice (Oryza sativa). J. Plant Physiol. 161, 63-68. doi: 10.1078/0176-1617-01156

Mian, M. R., Zhang, Y., Wang, Z. Y., Zhang, J. Y., Cheng, X., Chen, L., et al. (2008). Analysis of tall fescue ESTs representing different abiotic stresses, tissue types and developmental stages. BMC Plant Biol. 8:27. doi: 10.1186/1471-2229-8-27

Miller, G., Suzuki, N., Ciftci-Yilmaz, S., and Mittler, R. (2010). Reactive oxygen species homeostasis and signalling during drought and salinity stresses. Plant Cell Environ. 33, 453-467. doi: 10.1111/j.1365-3040.2009.02041.x

Mittler, R. (2002). Oxidative stress, antioxidants and stress tolerance. Trends Plant Sci. 7, 405-410. doi: 10.1016/S1360-1385(02)02312-9

Monjardino, P., Smith, A. G., and Jones, R. J. (2005). Heat stress effects on protein accumulation of maize endosperm. Crop Sci. 45, 1203-1210. doi: 10.2135/cropsci2003.0122

Ostrovskaya, L. K., Truch, V. V., and Mikhailik, O. M. (2009). Superoxide dismutase activation in response to lime-induced chlorosis. New Phytol. 114, 39-45. doi: 10.1111/j.1469-8137.1990.tb00371.x

Paulsen, G. M. (1994). "High temperature responses of crop plants," in Physiology and Determination of Crop Yield, eds K. J. Boote, J. M. Bennett, T. R. Sinclair, and G. M. Paulsen (Madison, WI: American Society of Agronomy, Crop Science Society of America, Soil Science Society of America), 365-389.

Queitsch, C., Hong, S. W., Vierling, E., and Lindquist, S. (2000). Heat shock protein 101 plays a crucial role in thermotolerance in Arabidopsis. Plant Cell 2, 479-492. doi: $10.1105 /$ tpc.12.4.479

Richardson, A. D., Duigan, S. P., and Berlyn, G. P. (2002). An evaluation of noninvasive methods to estimate foliar chlorophyll content. New Phytol. 153, 185-194. doi: 10.1046/j.0028-646X.2001.00289.x

Sairam, R. K., Srivastava, G. C., and Saxena, D. C. (2000). Increased antioxidant activity under elevated temperatures: a Mechanism of heat stress tolerance 
in wheat genotypes. Biol. Plant. 43, 245-251. doi: 10.1023/A:10027563 11146

Schoffl, F., Prandl, R., and Reindl, A. (1999). "Molecular responses to heat stress," in Molecular Responses to Cold, Drought, Heat and Salt Stress in Higher Plants, eds K. Shinozaki and K. Yamaguchi-Shinozaki (Austin, TX: R. G. Landes Co), 81-98.

Sharma, I., Ching, E., Saini, S., Bhardwaj, R., and Pati, P. K. (2013). Exogenous application of brassinosteroid offers tolerance to salinity by altering stress responses in rice variety Pusa Basmati-1. Plant Physiol. Biochem. 69, 17-26. doi: 10.1016/j.plaphy.2013.04.013

Shi, Q. H., Bao, Z. Y., Zhu, Z. J., Ying, Q. S., and Qian, Q. Q. (2006). Effects of different treatments of salicylic acid on heat tolerance, chlorophyll fluorescence, and antioxidant enzyme activity in seedlings of Cucumis sativa L. Plant Growth Regul. 48, 127-135. doi: 10.1007/s10725-005-5482-6

Shlizerman, L., Marsh, K., Blumwald, E., and Sadka, A. (2007). Iron-shortageinduced increase incitric acid content and reduction of cytosolic aconitase activity in Citrus fruit vesicles and calli. Physiol. Plant. 131, 72-79. doi: 10.1111/j.1399-3054.2007.00935.x

Shui, G., and Leong, L. P. (2002). Separation and determination of organic acids and phenolic compounds of fruit juices and drinks by high performance liquid chromatography. J. Chromatogr. A 977, 89-97. doi: 10.1016/S00219673(02)01345-6

Smirnoff, N. (1995). "Antioxidant systems and plant response to the environment," in Environment and Plant Metabolism: Flexibility and Acclimation, ed. N. Smirnoff (Oxford: Bios Scientific Publishers), 217-243.

Sun, Y. L., and Hong, S. K. (2011). Effects of citric acid as an important component of the responses to saline and alkaline stress in the halophyte Leymus chinensis (Trin.). Plant Growth Regul. 64, 129-139. doi: 10.1007/s10725-010-9547-9

Tian, J., Belanger, F. C., and Huang, B. R. (2009). Identification of heat stress-responsive genes in heat-adapted thermal Agrostis scabra by suppression subtractive hybridization. J. Plant Physiol. 166, 588-601. doi: 10.1016/j.jplph.2008.09.003

Vierling, E. (1991). The roles of heat shock proteins in plants. Annu. Rev. Plant Biol. 42, 579-620. doi: 10.1146/annurev.pp.42.060191.003051

Wahid, A., Gelani, S., Ashraf, M., and Foolad, M. R. (2007). Heat tolerance in plants: an overview. Environ. Exp. Bot. 61, 199-223. doi: 10.1016/j.envexpbot.2007.05.011
Wang, D., and Luthe, D. S. (2003). Heat sensitivity in a bentgrass variant. Failure to accumulate a chloroplast heat shock protein isoform implicated in heat tolerance. Plant Physiol. 133, 319-327. doi: 10.1104/pp.102. 018309

Wang, K., Zhang, X., Goatley, M., and Ervin, E. (2014). Heat shock proteins in relation to heat stress tolerance of creeping bentgrass at different $\mathrm{N}$ levels. PLoS ONE 9:e102914. doi: 10.1371/journal.pone.0102914

Wise, R. R., and Naylor, A. W. (1987). Chilling-enhanced photo-oxidation. The peroxidative destruction of lipids during chilling injury to photosynthesis and ultrastructure. Plant Physiol. 83, 278-282. doi: 10.1104/pp. 83.2.272

Xu, Q. Z., and Huang, B. R. (2000). Effects of air and soil temperature on carbohydrate metabolism in creeping bentgrass. Crop Sci. 40, 1368-1374. doi: $10.2135 /$ cropsci2000.4051368x

Xu, Y., and Huang B. R. (2009). Effects of foliar-appliede Ethylene inhibitor and synthetic cytokinin on creeping bentgrass to enhance heat tolerance. Crop Sci. 49, 1876-1884. doi: 10.2135/cropsci2008.07.0441

Xu, Y., Zhan, C., and Huang, B. R. (2011). Heat Shock proteins in association with heat tolerance in grasses. Int. J. Proteomics 2011, 1-10. doi: $10.1155 / 2011 / 529648$

Zhang, X., Wang, K., and Ervin, E. H. (2010). Optimizing dosages of seaweed extract-based cytokinins and zeatin riboside for improving creeping bentgrass heat tolerance. Crop Sci. 50, 316-320. doi: 10.2135/cropsci2009. 02.0090

Zhao, Z. J., Hu, L. X., Hu, T., and Fu, J. M. (2015). Differential metabolic responses of two tall fescue genotypes to heat stress. Acta Pratacult. Sin. 24, 58-69.

Conflict of Interest Statement: The authors declare that the research was conducted in the absence of any commercial or financial relationships that could be construed as a potential conflict of interest.

Copyright (c) $2016 \mathrm{Hu}$, Zhang, Xiang and Yang. This is an open-access article distributed under the terms of the Creative Commons Attribution License (CC BY). The use, distribution or reproduction in other forums is permitted, provided the original author(s) or licensor are credited and that the original publication in this journal is cited, in accordance with accepted academic practice. No use, distribution or reproduction is permitted which does not comply with these terms. 